腹部内蔵阻血症候群を伴った食道胃接合部癌の 1 手術例 旭川医科大学第 1 外科（主任：久保良彦教授）

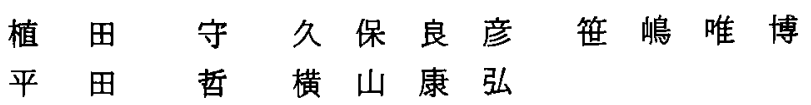

腹部内葴阻血症候群 (VI) を伴った食道胃接合部癌（EC 癌）を経験した。症例は51歳 男性で, 上腹部痛を主訴とし EC 癌が発見された。既往に胃潰瘍で胃切除術と, 左腸骨動

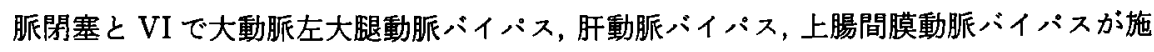
行されていた，術前造影では内葴動脈ハイハハスは閉塞し，根治術に伴い側副血行路が消 减する可能性の大きいことから，血行再建術が必須と考兄られた. R3切除後, 腹腔動脈 血栓内膜摘除+バッチ形成, 脾・上腸間膜動脈吻合術を先行し, Roux-Y 法で消化管を再 建した。

感染の可能性のある血行再建では人工血管の使用は好ましくない。また血流量の豊富 な血行再建では自家動脈の使用が好ましい，症例の如く脾動脈を利用する方法は合理的 であると考えられたので若干の文献的考察を加光報告した。

系引用語：腹部内喴阻血症候群, 残胃癌, 血行再建術

はじめに

腹部内缄阻血症候群 (Visceral Ischemia :VI) は古 くから腹部アンギーナ（abdominal angina）として知 られて㧍り，近年その血行再建症例が增加している。 しかし, 術式や再建血管の本数などにつき一定の見解 はない。

今回, VI を伴った残胃の食道胃接合部癌を経験した ので, 手術術式, リンパ節郭清範囲等について, 若干 の文献的考察を加兄報告する。

\section{症 例}

患者：51歳, 男性.

主訴：上腹部痛, 嬿下困難。

家族歴：特記すべきことなし..

既往歴：昭和56年, 胃潰瘍のため胃切除 (Billroth-I 法)を受けた。

昭和60年, 左腸骨動脈閉塞と, 腹部内葴阻血症候群 で，人工血管による大動脈一左腸骨動脈ハイイハスと， 自家伏在静脈による人工血管一肝動脈バイパス拉よび 一上腸間膜動脈バイパス術を受けた。

現病歴：昭和62年 8 月頃より食後の上腹部痛が出現 し近医にて内服治療を受けていた。昭和63年 1 月，踦

1988年11月21日受付 1989年 4 月26日採用
下困難も出現したため当科に入院した。

入院時現症：体格中等度，栄養不良，賓血，黄㾞な し. 胸部理学所見には異常はなかったが，腹部では左 右腸骨動脈領域に血管雑音を聴取した。

入院時検查成績: 末梢血液, 血清生化学検査は異常 なかった，腄瘍マーカーでは $\operatorname{AFP}(1,617.2 \mathrm{ng} / \mathrm{ml}) の$ 上昇を認めた。

胃透視所見：EaからCにかけての右壁に長径 $9 \mathrm{~cm}$ の鋸歯型所見を認めた（図 1).

内視鏡所見：上門歯列上り $38 \mathrm{~cm}$ から噴門部にかけ ての右後壁に，周堤の比較的明瞭な潰煌を伴う陥凹型 の所見がみられた。

CT 所見：食道, 噴門部は董場で肥厚していたが, 隣 接葴器への浸潤所見はなかった。遠隔臓器転移の所見 はなく、胸腔・腹腔内リンパ節の廆脹も認められなかっ た。

血管造影所見：昭和60年の血行再建術（図 2 左）の 内蔵動脈バイパスは閉塞していた。大動脈周囲の側副 血行路より脾動脈を経由して肝動脈が造影され，右内 腸骨動脈からの側副血行路で下腸間膜動脈は造影さ れ,さらに meandering mesenteric arteryを介して上 腸間膜動脈が造影されていた（図 2 右).

以上の検查所見より，残胃に発生した食道胃接合部 

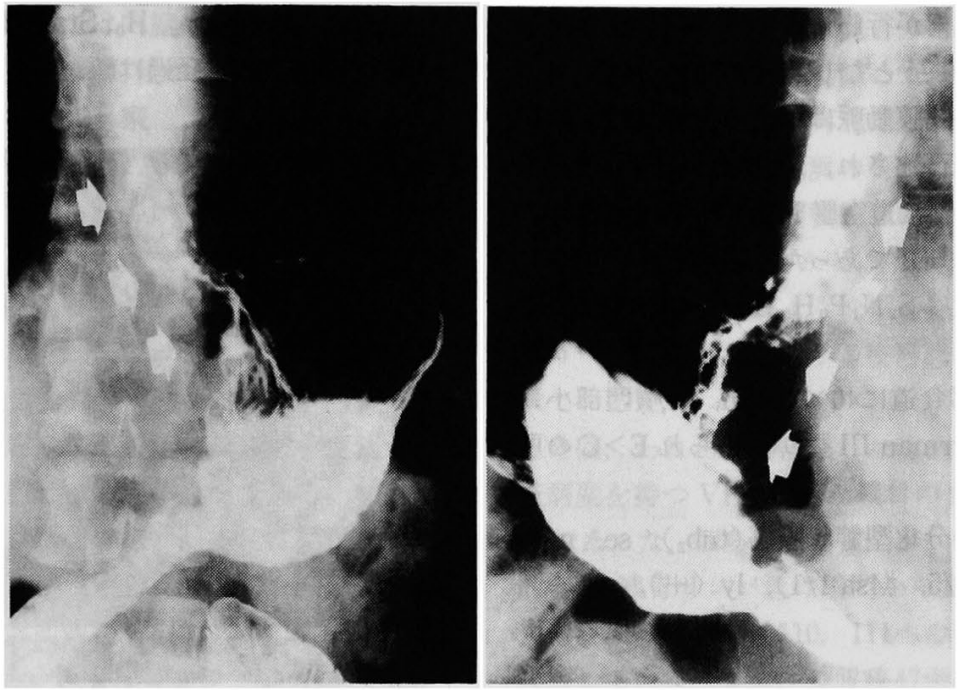

図 1 胃パリウム所見：下部食道右壁から胃噴門部小弯にかけての鋸歯型所見を示 于.

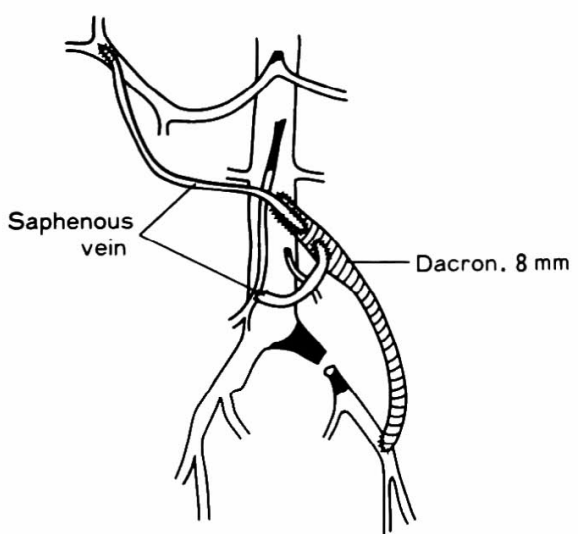

\section{昭和60年 手術}

図 2 前回の手術術式（右）と今回の手術の術前血管造影所見（左）

(1)大動脈周囲側副血行路. (2)脾動脈を介して肝動脈が造影された. (3)内腸骨動脈か

ら下腸間脈動脈への側副血行路. (4) Meandering Mesenteric Artery

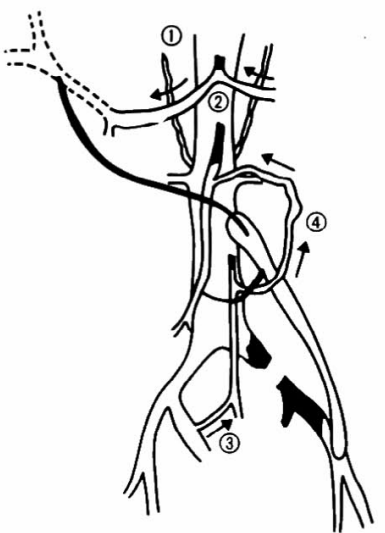

㭪前造影所見
癌 $(\mathrm{EC}$ 癌 $)$ で, 腹腔動脈, 上腸間膜動脈, 下腸間膜動 脈の 3 枝閉塞病変を持つVIを合併すると診断され た。根治術にさいし側副血行路も一緒に切除されるこ とから，肝血流ならびに消化管吻合部血流の確保と， $\mathrm{VI}$ 症状の軽減を目的に, 血行再建術の併用が予定され た.

手術術式：昭和63年 2 月 9 日, 右半側臥位, 斜切開
にて左開胸腹した. 術中所見は $\mathrm{E}>\mathrm{C}, \mathrm{S}_{2} \mathrm{~N}_{1} \mathrm{H}_{0} \mathrm{P}_{0} \mathrm{Pl}_{0}$ で 切除可能々判断され, 下部食道, 残胃, 膵尾脾合併切 除 R3 郭清, 胆䣼摘出術が行われた. 郭清に伴い大動脈 周囲の側副血行路が遮断され脾動脈が切除されたため 肝動脈の血流量低下が見られた。肝保護と予定された 消化管吻合部の血流確保のために血行再建術を先行さ せた。腹腔動脈には, 血栓内膜摘除と自家大伏在静脈 
片によるパッチ形成術が行われた，その結果，腹腔動 脈の血流量は $600 \mathrm{ml} / \mathrm{sec}$ となり, 肝動脈の拍動も良好 に触知された，上腸間膜動脈は中枢側の脾動脈を利用 して端端吻合により再建され，血流量は $400 \mathrm{ml} / \mathrm{sec}$ と なった．次いで胸腔内食道空腸 Roux-Y 再建が行われ た，吻合部の血行は良好であった（図 3 ）。

肉眼的病期進行度は $\mathrm{S}_{2} \mathrm{~N}_{1} \mathrm{P}_{0} \mathrm{H}_{0}$ Stage III, RIII の絶 対治癒切除であった。

切除標本では下部食道に $40 \times 20 \mathrm{~mm}$ ，胃噴門部小弯 に15×10mm の Borrman III 型が認められ $\mathrm{E}>\mathrm{C}$ の所 見であった。

組織学的には，中分化型管状腺癌 $\left(\operatorname{tub}_{2}\right), \mathrm{se}, \mathrm{n}_{1}$ (\# $13 / 3$, \#2 1/1, \#3 2/5, \#4sa 1/1), ly (+), v (-)
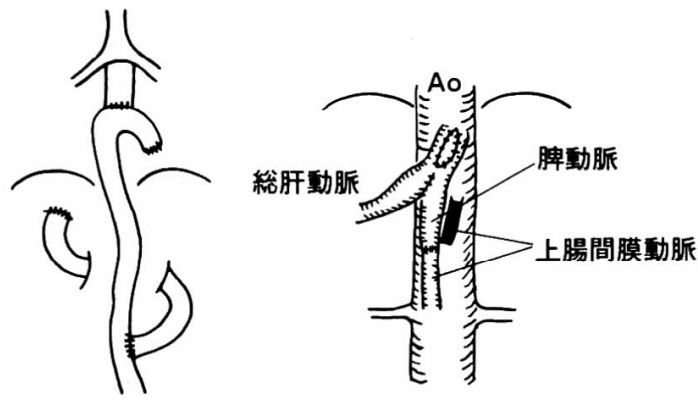

\section{消化管再建}

\section{血行再建}

図 3 手術術式：右；消化管再建 胸腔内食道空腸 Roux-Y 吻合. 左；血行再建 腹腔動脈内膜摘除＋ ハッチ形成（空白）脾動脈，上腸間膜動脈吻合
で進行度は se, $\mathrm{n}_{1}, \mathrm{p}_{0}, \mathrm{H}_{0}$, Stage III であった（図 4 ）。 術後経過：術後経過は順調で, 経口摂取後の上腹部

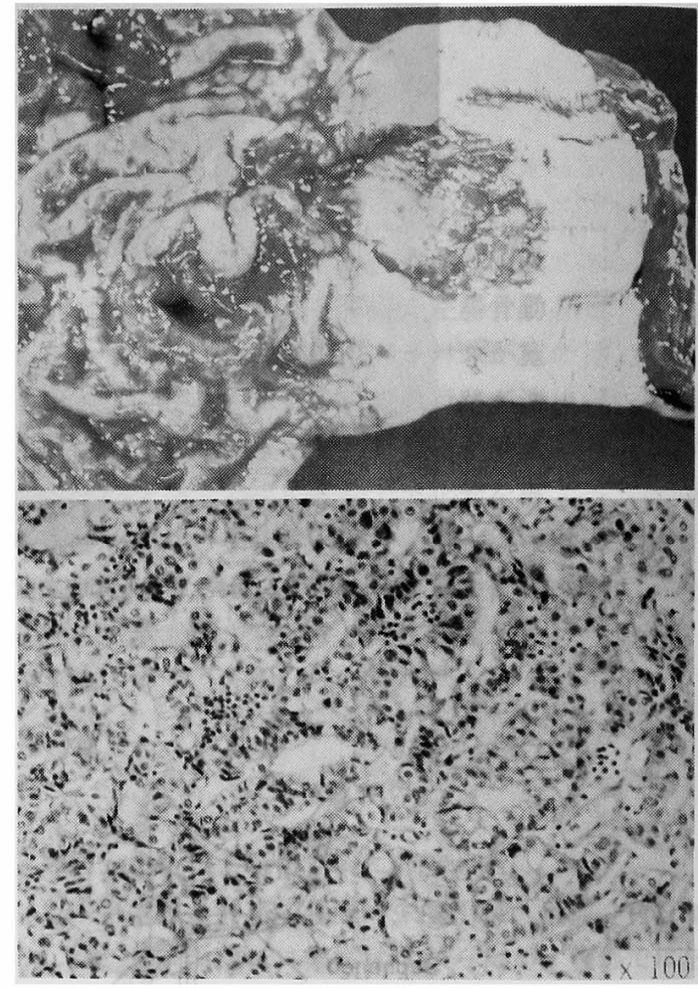

図 4 切除標本: 上：肉眼像下部食道に $40 \times 20$ $\mathrm{mm}$ ，噴門部に $15 \times 10 \mathrm{~mm}$ の Borrman III 型があり $\mathrm{C}<\mathrm{E}$ の所見であった。 下：組織像 中分化型管状 腺癌 $\left(\mathrm{tub}_{2}\right)$

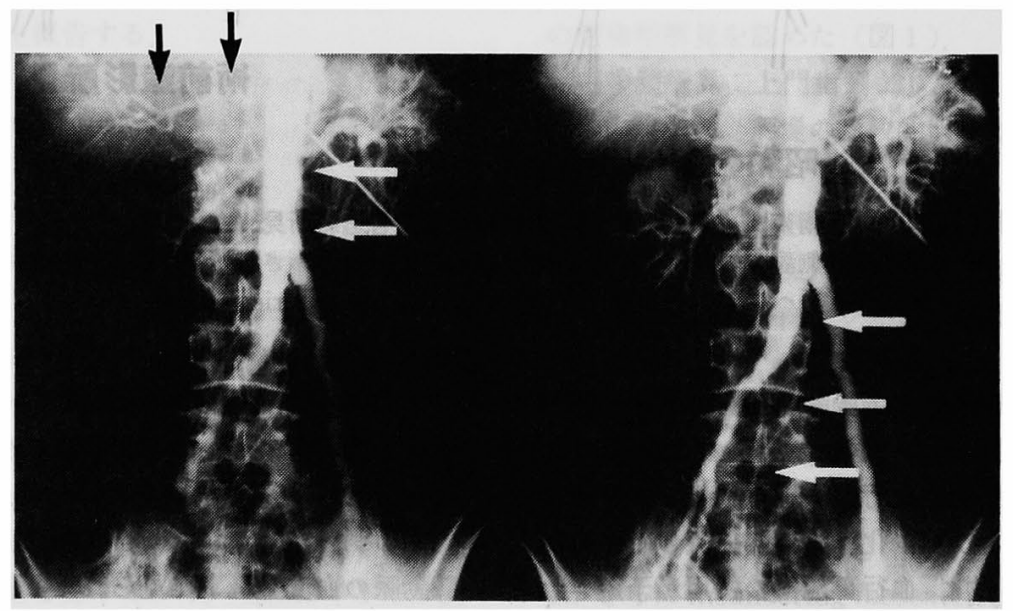

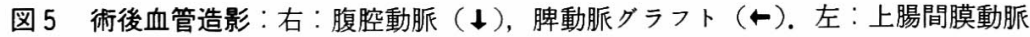

（ヶ）は良好に開存していた。 
痛は消失した，血管造影では内䁍血管バイパスの開存 は良好であり（図 5)，2 力月後に退院した。

\section{考 察}

VIは, 古くから Abdominal Anginaあるいは Intestinal Ischemia として知られている疾患で，食後に腸 管の相対的虚血がおこるために生ずるとされている。 腹腔動脈，上・下腸間膜動脈のらち 1 枝のみが閉塞し てもほとんど症状がなく，2枝以上に狭窄あるいは閉 塞病変がなければ発症しないとされている11. 食後の 腹痛，体重減少，下琍や腹部不定愁訴などを症状とす るので, 腹部悪性疾患との鑑別が必要である。

血管造影が重要な診断法であり, 病変は動脈起始部 付近にあるので，大動脈造影を行らべきである，撮影 方向は正面ととるに側面像が有用である ${ }^{2)}$.

1957年に Mikkelsen ${ }^{3)}$ が VI に対しての外科的治療

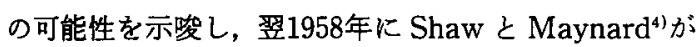
上腸間膜動脈閉塞の内膜摘除を, Derrick と Logan ${ }^{5}$ が腸骨動脈でのパイパスを報告していらい，近年，症 例数む多くなり術式等についてる議論のあるところで ある.

術式には分枝再移植，内膜摘除およびハィイパスが行 われている，分枝再移植は病変の軽度な症例にかぎら れているので報告は少ない. Stoney $5^{6}$ は経胸的内膜 摘除で好成績をあげ，この方法を推奨している．しか

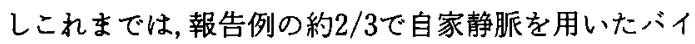
バスが行われて括り7，現在では，この術式が主流と なっている.一方, 腹部内臓動脈の血流量は $500 \mathrm{ml} / \mathrm{min}$ 前後の大血流量域であることから 扔よび代用血管の選択に問題がある゙2.

腹腔動脈より上の大動脈を中权端とする antegrade bypassは, この部の動脈硬化は少なく，経路も短く， 生理的である ${ }^{9)}$.これに対し, 腎動脈下の動脈を中权端 とする retrograde bypassは吻合部乱流を生ずること や経路が長くなることなどで晚期閉塞を生じやす (10).

代用血管の選択は吻合部位, 血流量, ハイイパス経路, 術野の污染の有無等で考えなければならない。自家静 脈は血流量と口径の mismatch 生ずる可能性がたか く，内膜肥厚に上ると思われる晚期閉塞が高率に発生 している9，人工血管による短い距離で血流量の多い バイパスは，姿势によるグラフトの変形も少なく開存 率は良好である゙11.したがって, 腹腔動脈や上腸間膜動 脈の主幹部の再建では人工血管（Dacron）が第一選択 であるが9，今回の症例のような消化管再建を伴った
污染手術では，血流量に見合5自家動脈の利用が望ま しい. 自家静脈は内臓動脈の末梢で再建せねばならな い例や下腸間膜動脈の再建などに限定される2).

多枝病变では腹腔動脈の再建は必須であるが，上腸 間膜動脈括よび下腸間膜動脈の同時再建の必要性につ いては議論がある。しかし，今日では，多枝再建を行っ た例では一枝再建例より晚期再発が少ないとの報告む あり ${ }^{10)}$ ，可能ななかぎり多枝再建を行らべきと考えら れている ${ }^{12)}$.

今回，われわれが経験した症例は，晚期閉塞例で 3 枝病変を持っ VI を伴った残胃の食道胃接合部癌 $(\mathrm{C}<$ E)であった．西ら ${ }^{13144}$ の噴門部への色素注入による検 討では, 残胃リンパ流は噴門から食道への経路があり， 食道浸潤残胃癌では110，111への転移率が高くなると 報告している．また，残胃癌47例のリンパ節転移の検 討では，1群リンパ節 $(1 ， 2 ， 3 ， 4 \mathrm{~s})$ の転移率と 2 群リンパ節 $(7 ， 8 ， 9 ， 10 ， 11)$ の転移率はほとん ど同率であり，進行した残胃癌では12，13，14，16の 転移率が高いと報告している。すなおち，根治を求め るために，われわれは左開胸腹で残胃全摘，膵体尾脾 合併切除，R3郭清 (107，110，111，112，1，2，3，4 s，7，8，9，10，11，12，16）を行った。

癌切除, 郭清に伴い大動脈周囲の側副血行路が切除 され脾動脈を介する肝血行が遮断された。消化管を処 理する污染手術であったので，肝血行路の再建のため に腹腔動脈の内膜摘除と自家静脈によるパッチ形成を 行った。また，食道と吻合を予定した空腸の血流改善 のため脾動脈之上腸間膜動脈を吻合したため，安全に 消化管再建が行われた。このような污染手術では，VI に対しての血行再建は限られる。本症例のよ5に内膜 摘除や自家動脈を利用する方法は合理的であると考え られた。

現在 VIは稀な疾患であるが，食生活の欧米化や高 齢化に伴い, 動脈硬化性の内嵗血管障害は増加するで あろ5. Reiner ら ${ }^{15}$ は死体の血管造影88例で，69例に 内臓血管の動脈硬化を認めており，腹腔動脈起始部で は $86 \%$, 上腸間膜動脈では $55 \%$, 下腸間膜動脈では $70 \%$ の病変があったと報告している，動脈硬化の強い消化 管の切除, 郭清, 再建例では, VI 孔考虑にいれ, 術前 血管造影をして，慎重に術式を検討しなければならな いと思われた。

おわりに

腹腔動脈閉塞と上・下腸間膜動脈閉塞のある腹部内 䁍阻血症候群を伴った残胃の食道胃接合部癌の 1 手術 
例を経験したので，文献的考察を加兄報告した。 文 献

1) Osmundson PI, Bernatz PE : Occlusive disease of abdominal arteries. Edited by JL Juergens, et al Peripheral Vascular disease. WB Saunders Company, Philadelphia, 1980, p295-326

2）久保良彦，笹嶋唯博：腹部臓器一とくに腹部内䁍 動脈および督動脈について一, 外科 49：1509 $-1516,1987$

3) Mikkelson WP : Intestinal angina; its surgical significance. Am J Surg 94 : 262-269, 1957

4) Shaw RS, Maynard DP: Acute and chronic thrombosis of the mesenteric arteries associated with malabsorption. N Engl J Med 258: 874 $-878,1958$

5) Derrick JR, Logan WD: Mesenteric arterial insufficiency. Surgery $44: 823-829,1958$

6) Stoney DJ, Ehrenfeld WK, Wiley EJ : Revascularization methods and chronic visceral ischemia caused by atherosclerosis. Ann Surg $186: 468-476,1977$

7) Bergan JJ, Yao JST: Chronic intestinal ischemia. Edited by Rutherfold RB Vascular surgery. (2nd ed) WB Saunders Company, Philadelphia, 1984, p964-971

8) Rapp JH, Reilly LM, Qvarfordt PG, et al: Durability of endarterectomy and antegrade grafts in the treatment of chronic visceral ischemia. J Vasc Surg $3:$ 799-806, 1986

9) Stoney RJ, Reilly LM, Ehrenfeld WK, et al: Chronic mesenteric ischemia and surgery for chronic visceral iscemia. Edited by Wilson SE et al Vascular Surger - Principles and practice -. McGraw Hill Book, New York, 1987, p672 $-684$

10) Hollier LH, Bernatz PE, Pairo-Lero PC, et al : Surgical managemant of chronic intestinal ischemia-Reappreisai-. Surgery $90: 940-946$, 1981

11) Stanton PE, Hollier PA, Seidal TW, et al: Chronic intestinal ischemia - Diagnosis and therapy-. J Vasc Surg 4:338-344, 1986

12) Baur GM, Millay DJ, Taylor LM, et al : Treatment of chronic visceral ischemia. Am J Surg $148: 138-144,1984$

13）西 満正, 東郷実元, 太田恵一郎他：残胃のリンパ 流，外科治療 $57: 279-284,1987$

14）西 満正，愛甲 孝：消化管のリンバ流と癌の転 移, リンパ学 7:1-11, 1984

15) Reiner L, Jimenez FA, Rodrigues FL: Atherosclerosis in the mesenteric circulation : Observations and correlations with aortic and coronary atherosclerosis. Am Heart J 66 : 200-209, 1963

\title{
A CASE OF CARCINOMA OF THE ESOPHAGO-GASTRIC JUNCTION WITH VISCERAL ISCHEMIA
}

\author{
Mamoru UEDA, Yoshihiko KUBO, Tadahiro SASAJIMA, Satoshi HIRATA and Yashiro YOKOYAMA \\ First Department of Surgery, Asahikawa Medical College, Asahikawa, Japan
}

A 51-year-old man was admitted to our department for operation for carcinoma of the esophago-gastric junction who had undergone partial gastrectomy 7 years ago for an ulcer. Moreover, two years ago, he underwent aorto-toleft femoral bypass combining wiht bypass-to the common hepatic and the superior mesenteric artery to treat left iliac arterial obstruction and visceral ischemia. Preoperative aortography revealed an obstruction of these visceral arterial bypass graft.

Because of a possibility jeopardizing collateral pathyway to the hepatic and superior mesenteric artery, revascularization was done after total remnant gastrectomy with pancreato-splenectomy prior to alimentary tract reconstruction. The visceral blood flow improved clearly after endarterectomy and saphenous vein patch grafting to celiac axis and anastomosis between the proximal splenic and superior mesenteric artery.

In these circumstances such as the patient presented, a synthetic graft is not appropriate for use owing to its possible infection. Moreover, an autogenous arterial graft is judged to be superior to a vein graft for the bypass which is rich in blood flow. The use of the splenic artery in this manner is thought to be rational. 